\title{
PERLINDUNGAN HUKUM TERHADAP EKSPRESI BUDAYA TRADISIONAL DALAM PERSPEKTIF UNDANG UNDANG HAK CIPTA
}

\author{
Hendra Djaja \\ Fakultas Hukum Universitas Merdeka Malang \\ Jl. Terusan Raya Dieng No. 62-64 Malang \\ hendra.djaja@unmer.ac.id
}

\begin{abstract}
According to the statistics year 2010 in Indonesia there are more than a thousand nations across nusantara, so that indonesia is very rich in diversity of the traditional cultural expressions. The traditional cultural expressions is "intangible culture creation" an ancestral estate that must be maintained, maintained, developed and protected from exploitation and unilateral claim a foreign country or missappropriation. The creator of the work of cultural expression generally not recognised, so that an obligation to protect the traditional cultural expressions especially being on the state as copyright holders and to indigenous as caretaker the origin of the birth of creation culture tersebut.jika ownership of intellectual property in regime trips is individual so that in protection the traditional cultural expressions ownership of their rights is communal namely to be shared indigenous caretaker creation traditional culture concerned. As the holder of the power of the traditional cultural expressions, the government is given the right of the management or a right economic exploitation (economic rights) an expression of the traditional culture of rights moralnya while (moral rights), remain on the community. The law enforcement abuse of the traditional cultural expressions existing during this is less exhilarating. Several factors thought to cause the ineffectiveness of law enforcement abuse by foreign parties claiming unilaterally cultural expression the traditional. Copyright Act Number 28 Year 2014 expected more effective in legal protection the traditional cultural expressions.
\end{abstract}

Keywords: Traditional Culture Expression, Claim Abuse, Communal Right.

\begin{abstract}
ABSTRAK
Menurut data Badan Pusat Statistik tahun 2010 di Indonesia terdapat lebih dari seribu suku bangsa yang tersebar di seluruh nusantara, sehingga Indonesia sangat kaya dengan keberagaman Ekspresi Budaya Tradisional. Ekspresi Budaya tradisional adalah "kreasi budaya tak benda" warisan leluhur sehingga wajib dijaga, dipelihara, dikembangkan dan dilindungi dari eksploitasi dan klaim sepihak negara asing (missappropriation). Pencipta karya Ekspresi Budaya umumnya tidak dikenallagi, sehingga kewajiban untuk melindungi Ekspresi Budaya Tradisional terutama berada pada negara sebagai pemegang hak cipta dan kepada masyarakat adat selaku pengemban asal usul lahirnya kreasi budaya tersebut.Jika kepemilikan hak intelektual dalam rezim TRIPs bersifat individual maka dalam perlindungan Ekspresi Budaya Tradisional kepemilikan haknya bersifat komunal yakni milik bersama masyarakat adat pengemban Kreasi Budaya Tradisional bersangkutan. Sebagai pemegang kuasa Ekspresi Budaya Tradisional, pemerintah diberikan hak pengelolaan atau eksploitasi hak ekonomi (economic rights) Ekspresi Budaya Tradisional sedangkan hak moralnya (moral rights), tetap berada pada masyarakat pengembannya. Penegakan hukum penyalahgunaan Ekspresi Budaya Tradisional yang ada selama ini, kurang menggembirakan. Beberapa faktor diduga menyebabkan tidak efektifnya-penegakan hukum penyalahgunaan oleh pihak asing yang mengklaim secara sepihak Ekspresi Budaya Tradisional tersebut. Undang Undang Nomor 28 Tahun 2014 tentang Hak Cipta diharapkan lebih efektif dalam perlindungan hukum Ekspresi Budaya Tradisional.
\end{abstract}

Kata Kunci: Ekspresi Budaya Tradisional, Hak Komunal, Penyalahgunaan Sepihak. 
Undang Undang Nomor 28 Tahun 2014 tentang Hak Cipta telah mengatur perlindungan hukum atas Ekspresi Budaya Tradisional sebagai salah satu obyek perlindungan hak cipta. Perlindungan hukum terhadap Ekspresi Budaya Tradisional ini telah mengingatkan pada kejadian beberapa tahun lalu. Kejadian yang dimaksud adalah klaim sepihak (missapropprriation) negara jiran Malaysia terhadap beberapa warisan budaya tradisisional yang berasal dari berbagai daerah di Indonesia. Sementara pemerintah Malaysia sendiri telah mengesahkan Undang Undang Tahun 2005 - AKTA 645 tentang Warisan Kebangsaan, khususnya pasal 69 dan pasal 70 dengan tujuan melindungi warisan budaya kebangsaannya.

Klaim sepihak terhadap Ekspresi Budaya Tradisional dari Indonesia itu mempunyai dua makna penting yaitu pertama, warga negara Malaysia hanya melakukan "representasi" karya seni tradisional dari leluhurnya yang kebetulan, berasal dari Indonesia atau pengertian kedua,pemerintah Malaysia telah mengakui Ekspresi Budaya Tradisional itu kedalam perundang-undangan sebagai kekayaan intelektual warisan budaya asli mereka sendiri.

Hal ini jika klaim itu sesuai dengan pengertian pertama, maka kita harus berterimakasih, karena mereka telah ikut "melestarikan" Ekspresi Budaya Tradisional yang berasal dari Indonesia. Tetapi jika klaim itu telah dilakukan secara formal melalui perundangan kekayaan intelektualnya, permasalahanya tidak lagi sederhana. Bagi sebagian masyarakat kita jika klaim sepihak itu benar, ini bisa dianggap sebagai sikap "merendahkan" bangsa Indonesia, apalagi jika Ekspresi Budaya Tradisional yang diklaim, tidak berlaku Masyarakat Adat Pengembannya secara turun temurun ada di teritorial Indonesia.

Jika dikatakan kita lalai dalam perlindungan kekayaan intelektual atas Ekspresi Budaya Tradional, sebenarnya kurang tepat mengingat sebelumnya kita sudah memiiki Undang Undang
Nomor 19 Tahun 2002 tentang Hak Cipta. Di situ juga telah diatur bahwa negara merupakan Pemegang Hak atas folklore dan hasil ekspresi tradisional yang menjadi milik bersama (hak komunal) masyarakat adat pengembannya. Soal inventarisasi dan kewajiban melakukan pencatatan oleh pemerintah tersebut, mungkin merupakan salah satu faktor kelemahan cukup serius. Pada konteks ini negara jiran Malaysia termasuk dalam banyak hal, selalu lebih maju melangkah.

Adanya Undang Undang Nomor 28 Tahun 2014 tentang Hak Cipta, sekarang dipertanyakan bagaimanakah "nasib" dari Rancangan Undang Undang tentang Perlindungan dan Pemanfaatan Kekayaan Intelektual Pengetahuan Tradional dan Ekspresi Budaya Tradional (RUU PTEBT) yang sudah dalam proses legislasi? Kedudukan Undang Undang Nomor 28 Tahun 2014 tentang Hak Cipta merupakan sistem sui generis dari perundangan yang mengatur tentang Perlindungan dan Pemanfaatan Hak Kekayaan Intelektual Pengetahuan Tradisional dan Ekspresi Budaya Tradisional, sebagaimana RUU PTEBT.

Konsep perlindungan hukum atas pemanfaatan hasil Ekspresi Budaya Tradisional adalah perlindungan atas karya dalam wujud berbagai karya baik "verbal", "tulisan" atau bentuk kombinasinya, sebagaimana sekarang telah diatur dalam Undang Undang Nomor 28 Tahun 2014 tentang Hak Cipta. Sedangkan dalam konsep perlindungan kekayaan intelektual dan pemanfaatan atas 'Pengertahuan Tradisional khususnya keberagaman sumberdaya hayati (biological diversity), mengikuti konsep perlindungan hak kekayaan intelektual di dalam rezim TRIPs seperti paten, merek atau indikasi geografis. Perbedaan lainnya adalah konsep perlindungan hak kekayaan intelektual di dalam TRIPs sifatnya eksklusif melindungi kepentingan hak milik individual, sedangkan konsep pelindungan hukum atas pemanfaatan hasil ekspresi budaya tradisional lebih bersifat perlindungan hak milik bersama masyarakat sehingga sifatnya komunal. 
Apa pentingnya perlindungan hukum terhadap Ekspresi Budaya Tradisional? Menurut data dari Badan Pusat Statistik tahun 2010, telah mencatat jumlah suku yang ada di Indonesia adalah 1.128 suku bangsa. Setiap suku bangsa tersebut memiliki keberagaman etnik serta budayanya sendiri. Semuanya merupakan potensi sebagai warisan budaya bangsa yang tidak ternilai, sehingga patut dilindungi, dilestarikan dan dikembangkan sebagai aset bangsa yang juga bernilai ekonomi (Jawa Pos, 2016).

Upaya pemerintah untuk mencegah atau melindungi penyelahgunaan hasil kreasi Pengetahuan Tradisional dan hasil kreasi Ekspresi Budaya Tradisional di tingkat internasional, sebenarnya sudah cukup. Beberapa konvensi internasional telah diratifikasi oleh pemerintan misalnya Convention for on Safeguarding of the Intangible Cultural Heritage 2003 dan Convention on The Protection of The Diversity of Cultural Expression 2005 hasil dari Forum UNESCO.

Sekarang persoalannya adalah bagaimanakah mencegah adanya klaim pihak asing seperti pada kasus iklan promosi pariwisata Malaysia di TV kabel Discovery Channel dalam Enigmatie Malaysia, yang kontennya seolah mengakui tarian Pendet atau lagu Rasasayange merupakan warisan kebangsaan malaysia atau pada kasus klaim sepihak atas motif bunga (fleur) milik indigeous masyakat Bali yang di klaim oleh PT. Karya Tangan Indah yang telah mengalihkan hak-haknya (eksklusif) kepada John Hardy Limited. Kasus lain misalnya ukiran jepara yang di klaim milik PT. Harrison \& Gil Java.

Selanjutnya dari pengamatan selama ini, beberapa faktor yang berpengaruh terhadap lemahnya penegakan hukum terhadap penyalahgunaan tanpa ijin atas berbagai karya Ekspresi Budaya di Indonesia antara lain karena rezim hak kekayaan intelektual yang individual belum sepenuhnya mampu melindungi Ekspresi Budaya Tradisional dan sikap masyarakat pengembannya sendiri justru "tidak peduli" karena perlindungan tersebut tidak memiliki keuntungan secara ekonomi.

Faktor lain yang juga berpengaruh terhadap lemahnya penegakan hukum tersebut adalah pengaturan perlindungan Ekspresi Budaya Tradisional yang selama ini diatur dalam Undang Undang Nomor 12 Tahun 2012 masih kurang efektif, akibat dari belum ada peraturan pelaksanannya atau karena terhambatnya RUU Perlindungan dan Pemanfaatan Pengetahuan Tradisional dan Ekspresi Budaya Tradisional atau dalam proses pencatatan resmi, syarat originalitas (keaslian) tidak terpenuhi.

Paparan di atas, permasalahannya adalah bagaimanakah konsep perlindungan Ekspresi Budaya Tradisional dalam Undang Undang Nomor 28 Tahun 2014 tentang Hak Cipta dan faktor apa saja yang selama ini berpengaruh terhadap lemahnya penegakan hukum penyalahgunaan tanpa ijin karya Ekspresi Budaya Tradisional tersebut?

\section{Analisis dan Pembahasan}

Sejak tahun 2008 pemerintah Indonesia cukup serius untuk mulai menyusun Rancangan Undang Undang sui generis untuk melindungi eksploitasi hak kekayaan intelektual atas karya Pengetahuan Tradisional maupun karya hasil Ekspresi Budaya Tradisional. Tujuan pembentukan Rancangan Undang Undang tesebut agar Pengetahuan Tradisional dan Ekspresi Budaya Tradisional terhindar dari penyalahgunaan tanpa ijin terutama oleh pihak asing. Saat ini perlindungan hukum atas hak kekayaan intelektual Ekspresi Budaya Tradional secara khusus diatur dalam Undang Undang Nomor 28 tahun 2014 tentang Hak Cipta yang menggantikan Undang Undang Nomor 19 Tahun 2002.

Indonesia ditingkat internasional juga cukup aktif berpartisipasi pada berbagai forum, untuk mencari solusi dan format perlindungan hukum 
terhadap Pengetahuan Tradisional dan Ekspresi Budaya Tradisional, diantaranya United Nations International Year the Worlds Indigenous yang bertujuan melindungi dan mengembangkan perwujudan dari masa lalu, sekarang dan masa depan atas kreasi budaya, seperti pusaka, desain, upaca, teknologi, seni visual, pertunjukan, sastra serta hak menggugat gantirugi atas harta budaya dan seterusnya.

Konvensi internasional pertama tentang Hak Budaya dan Intelektual Penduduk Asli, diadakan di Selandia Baru pada tahun 1993 yang berhasil mencetuskan Deklarasi Mataatun yang pada dasarnya menyatakan:

1. Hak untuk melindungi pengetahuan tradisional adalah sebagian dari hak menentukan nasib sendiri;

2. Masyarakat asli seharusnya menentukan untuk dirinya sendiri apa yang merupakan kekayaan intelektual dari budaya mereka;

3. Alat perlindungan hukum yang ada kurang memadai;

4. Kode etik harus dikembangkan untuk ditaati pengguna luar ketika mencatat pengetahuan tradisional dan adat;

5. Sebuah lembaga harus dibentuk untuk melestarikan dan memantau komersialisasi karyakarya dan pengetahuan tradisional ini, untuk memberi usulan kepada penduduk asli mengenai bagaimana mereka dapat melindungi sejarah budayanya dan untuk berunding dengan pemerintah tentang undang undang yang berdampak pada hak tradisional;

6. Sebuah sistem tambahan mengenai hak budaya dan kekayaan intelektual harus dibentuk yang mengakui: (1) collective ownership dan berlaku surut, (2) protection against debasement of culturally significant items (pelecehan benda budaya penting), (3) co-operative rather than competitive framework (kerangka yang mementingkan kerjasama dibandingkan jika bersaing, (4) first beneficiaries to be direct descendants of the traditional guardiants of the knowledge (yang paling berhak adalah keturunan dari pemelihara pengetahuan tradisional).

Kemajuan yang penting baru dirasakan setelah disepakatinya Convention for The Safeguarding of The Intangible Cultural Heritage 2003 dan Convention on The Protection and Promotion of The Diversity of Cultural Expression 2005 dalam forum UNESCO. Konvensi ini telah diratifikasi pemerintah Indonesia dalam Peraturan Presiden RI Nomor 78 Tahun 2007 tentang Pengesahan Konvensi untuk Perlindungan Warisan Budaya Tak Benda. Sedangkan Convention The Protection and Promotion of the Diversity of Cultural Expression 2005, diratifikasi melalui Peraturan Presiden RI Nomor 78 Tahun 2011 tentang Pengesahan Konvensi Proteksi dan Promosi Kenekaragaman Ekspresi Budaya.

Konvensi tersebut telah dinyatakan pentingnya perlindungan Pengetahuan Tradisional serta Ekspresi Budaya Tradisional. Konvensi tersebut merupakan jalan bagi negara berkembang untuk melindungi kekayaan Pengetahuan Tradisional dan Ekspresi Budaya Tradisionalnya. Hal ini sekaligus bertujuan sebagai pedoman dalam pembentukan undang undang nasional terkait perlindungan Pengetahuan Tradisional dan Ekspresi Budaya Tradisionalnya yang bersifat sui generis.

Sudut pandang konsep hak kekayaan intelektual, kedua konvensi telah menegaskan kembali pentingnya perlindungan terhadap "Hak Moral Komunal"sebagai bagian "Hak moral suatu bangsa" pemilik warisan kekayaan Pengetahuan Tradisional dan Ekspresi Budaya Tradisional. Oleh karenanya penegakan hukum untuk menjaga baik hak ekonomi (economic rights) maupun hak moral (moral rights) atas eksploitasi setiap karya warisan bangsa tersebut diserahkan pada pemerintah sebagai pemegang hak sehingga dapat dikelola dengan baik. 


\section{Terminologi}

Sebelum pembahasan tentang Ekspresi Budaya tradisional perlu juga diuraikan keterkaitan substansinya dengan pengetahuan tradisional, karena memiliki substansi dasar yang sama yakni kreasi dan inovasi masyarakat tradisional. Pengetahuan tradisional adalah karya intelektual di bidang pengetahuan dan teknologi tradisional mengandung unsur karakteristik warisan tradisional yang dihasilkan, dikembangkan dan dipelihara oleh komunitas atau masyarakat tertentu. Sedangkan ekspresi budaya tradisional adalah karya intelektual dalam bidang seni, termasuk ekspresi sastra yang mengandung unsur karakteristik warisan tradisional yang dihasilkan, dikembangkan dan dipelihara oleh kominitas dan masyarakat tertentu.

Dengan demikian maka Kustodian atau pemilik hak dari Pengetahuan Tradisional dan Ekspresi Budaya Tradisional adalah masyarakat atau komunitas tradisional yang memelihara dan mengembangkan pengetahuan tradisional atau Ekspresi budaya tradisional tersebut secara tradisional dan komunal.

Sedangkan substansi Pengetahuan Tradisional yang dilindungi mencakup kecakapan teknik (know how), ketrampilan, inovasi, konsep, pembelajaran dan praktik kebiasaan lainnya yang membentuk gaya hidup masyarakat tradisional termasuk di antaranya pengetahuan pertanian, pengetahuan teknis, pengetahuan ekologis, pengetahuan pengobatan dan tatacara penyembuhan serta pengetahuan yang terkait dengan sumber daya genetik.

Selanjutnya sebagaimana ketentuan pasal 38 Undang Undang Nomor 28 Tahun 2014 tentang Hak Cipta, bahwa Ekspresi Budaya Tradisional yang dilindungi mencakup salah satu atau kombinasi bentuk ekspresi berikut ini:

a) Verbal tekstual, baik dalam bentuk lisan maupun tulisan yang berbentuk prosa maupun puisi, dalam berbagai tema dan kandungan isi pesan yang dapat berupa karya sastra maupun narasi informatif;

b) Musik, mencakup antara lain vokal, instrumental atau kombinasinya;

c) Gerak mencakup antara tarian, beladiri dan permainan;

d) Teater mencakup antara lain pertunjukan wayang dan sandiwara rakyat;

e) Seni rupa baik dalam bentuk dua dimensi maupun tiga dimensi yang terbuat dari berbagai macam bahan, seperti kulit, kayu, bambu, logam, batu, keramik, kertas, tekstil dan macam bahan lain atau komboinasinya, dan

f) Upacara adat yang juga mencakup pembuatan alat dan bahan serta penyajiannya.

Pasal 38 ayat (3) Undang Undang Nomor 28 Tahun 2014 tentang Hak Cipta dikatakan bahwa: "Penggunaan ekspresi budaya tradisional tersebut, harus memperhatikan nilai-nilai yang hidup dalam masyarakat pengembannya". Adapun dalam penjelasan pasal tersebut yang dimaksud dengan nilai-nilai yang hidup dalam masyarakat pengembannya adalah adat istiadat, norma hukum adat, norma kebiasaan, norma sosial dan norma yang luhur lain yang dijunjung tinggi oleh masyarakat tempat asal, yang memelihara, mengembangkan dan melestarikan ekspresi budaya tradisional.

Pembahasan tentang perlindungan hukum Ekspresi Budaya Tradisional sangat terkait dengan tiga unsur penting yaitu:

1) Adanya penyalahgunaan Ekspresi Budaya Tradisional oleh pihak asing yang diantaranya menggunakan sistem hak kekayaan intelektual;

2) Terikatnya negara untuk menerapkan sistem perlindungan Hak Kekayaan Intelektual;

3) Buruknya sistem perlindungan Ekspresi Budaya Tradisional. 
Diperkirakan bahwa penyalahgunaan pemanfaatan ekspresi budaya khususnya oleh negara asing semakin meningkat diwaktu akan datang. Kasus klaim negara asing beberapa waktu yang lalu bisa dijadikan patokan bahwa tidak menutup kemungkinan kasus serupa terulang kembali. Kebanyakan kasus, klaim sepihak terhadap ekspresi budaya tradisional oleh pihak asing tersebut, tentu tidak pada klaim kepemilikan semata tetapi juga pada klaim Hak Kekayaan Intelektual untuk hak ekslusifnya.

Sebagai contoh pada persoalan "klaim sepihak" melalui iklan pariwisata yang berasal dari Malaysia beberapa tahun yang lalu, dapat dijadikan sebagai titik tolak bagi Indonesia lebih serius melindungi aset nasional melalui perlindungan Ekspresi Budaya Tradisionalnya. Pertanyaan adalah apakah pemerintah Malaysia secara formal telah mengakui berbagai Ekspresi Budaya Tradisional yang turun temurun faktanya memang berasal dari Indonesia?

Menjawab persoalan itu maka harus melihat Undang Undang Tahun 2005 - AKTA 645 tentang Warisan Kebangsaan dari negara Malaysia.

- Pasal 69 menyebutkan:

"Mana-mana Warisan Kebangsaan yang dipunyai atau yang dimiliki oleh mana mana orang selain Kerajaan Persekutuan atau Kerajaan Negeri boleh terus berada dalam milikan pemunya, penjaga atau pemegang amanahnya".

- Selanjutnya pada pasal 70 disebutkan:

1. "Maka tidak boleh ada pertukaran berkenaan dengan pemunyaan mana-mana Warisan Kebangsaan kecuali melalui:

(a) pewarisan; atau

(b) penjualan, dengan kelulusan Pesuruhjaya terlebih dahulu;

2. Jika pemunya, penjaga atau pemegang amanah berniat untuk menjual suatu Warisan Kebangsaan, pemunya, penjaga atau pemegang amanah itu hendaklah memberi keutamaan kepada
Pesuruhjaya untuk membeli Warisan Kebangsaan itu pada nilai yang dipersetujui atau atas arahan Pesuruhjaya untuk diuruskan mengikut apa-apa cara yang difikirkan patut oleh Pesuruhjaya;

3. Jika terdapat apa-apa pertikaian antara Pesuruhjaya dengan pemunya mengenai pampasan yang munasabah bagi Warisan Kebangsaan itu, pertikaian itu hendaklah dirujukkan kepada Menteri yang keputusannya adalah muktamad;

4. Jika suatu penjualan telah dilakukan menurut perenggan (1) (b), pemunya, penjaga atau pemegang amanah dan pembeli hendaklah memberitahu secara tertulis kepada Pesuruhjaya dalam masa tiga puluh hari selepas pertukaran pemunyaan dan Pesuruhjaya hendaklah menyebabkan dibuat pindaan yang perlu dalam Daftar".

Dari substansi pasal 69 tersebut dapat dikatakan bahwa pemerintah malaysia tetap menyerahkan kreasi dan karya warisan kebangsaan tetap berada pada masyarakat pemilik warisan kebangsaan bersangkuitan untuk dijaga dan dipelihara dengan baik. Apabila dikaitkan misalnya dengan kasus "klaim" kesenian Reog maka pemerintah tetap mengakui bahwa kesenian Reog tersebut tetap diakui sebagai kesenian yang hidup dan berkembang di kalangan warganegaranya keturunan yang berasal dari Ponorogo. Jadi di sini sebenarnya tidak ada klaim sepihak secara langsung oleh kerajaan (pemerintah).

Namun demikian pada pasal berikutnya, dengan jelas dikatakan bahwa kreasi warisan kebangsaan tersebut tidak boleh dialihkan dengan tujuan agar tetap berada pada masyarakat pemiliknya untuk dijaga dan dilestarikan. Pemindahan kepemilikan atas warisan kebangsaan tersebut, hanya boleh dilakukan melalui sistem hukum waris. Akan tetapi jika oleh masyarakat pemiliknya akan dieksploitasi hak ekonominya (bukan hak moral), maka harus dengan seijin instansi resmi (pesuruhjaya) 


\section{Jurnal Cakrawala Hukum \\ Vol.7, No.1 Juli 2016: 18-29}

pemerintah yang berwenang atas pengelolaan warisan kebangsaan, disertai alasannya secara tertulis untuk kemudian dicacat (didaftar). Dalam hal ini maka pihak pemerintah menjadi pihak pertama yang memperoleh prioritas membelinya dengan nilai yang disepakati bersama. Hal ini pemerintah berkedudukan sebagai pemegang hak ekonominya sedangkan hak moral tetap berada pada mayarakat adatnya.

Dengan pengaturan warisan kebangsaan dalam ke dua pasal tersebut, maka seluruh Ekspresi Budaya Tradisional yang dimiliki oleh orang keturunan Indonesia sebagai pengembannya saat ini telah menjadi warga negara Malaysia, kedudukan pihak pemerintah (kerajaan) hanya menjadi pengelola hak eksklusif sedangkan hak moralnya tetap menjadi milik masyarakat. Oleh karenanya secara tidak langsung, dapat disimpulkan Ekspresi Budaya Tadisional yang asalnya dari Indonesia, sekarang menjadi milik Malaysia.

\section{Faktor faktor yang mempengaruhi kurang maksimalnya perlindungan Ekspresi Budaya Tradisional}

Berdasarkan pengamatan pada satu dekade berlakunya Undang Undang Nomor 19 Tahun 2002 tentang Hak Cipta, dapatlah dikemukan beberapa faktor yang secara substansial berpengaruh terhadap kurang efektifnya perlindungan Ekspresi Budaya Tradisional diataranya:

\section{Perlindungan Rezim Hak Kekayaan Intelektual Tidak Maksimal.}

Secara teoritis diberikannya hak eksklusif kepada pencipta atau penemu suatu karya dimaksudkan sebagai bentuk penghargaan (rewad) atas pengorbanan pencipta dalam menghasilkan tersebut. Di sini lahirnya suatu karya telah dikonsepsikan sebagai pengorbanan dari pencipta, baik terkait soal pemikiran, tenaga, waktu atau materi.
Dengan pengorbanan demikian dipandang perlu untuk menghormatinya yang diberikan dalam bentuk hak eksklusif.

Secara kategoris hasil kreasi intelektual pada rezim HKI biasanya dapat dibedakan ke dalam "Hak Cipta" dan "Hak Milik Industri". Jika hak cipta mencakup karya bidang ilmu penegtahuan, seni dan sastra maka hak milik industri meliputi obyek hak seperti paten, merek, desain industri, rahasia dagang, desain tata letak sirkuit terpadu dan perlindungan varietas tanaman. Hak intelektual seperti ini bersifat melindungi kepentingan individual.

Secara kategoris rezim Hak Kekayaan Intelektual juga mengakui adanya kepemilikan hak intelektuial yang bersifat melindungi kepentingan komunal. Hak komunal tersebut ada pada obyek perlindungan seperti Pengetahuan Tradisional, Ekspresi Budaya Tradisional, Indikasi geografis serta indikasi asal.

Konsep perlindungan karya dan Kreasi Pengetahuan Tradisional dan Ekspresi Budaya Tradisional dari sudut hak kekayaan intelektual dapat dikemukakan sebagai berikut:

1) Status hukum setiap karya pengetahuan tradisional dan ekspresi budaya tradisional merupakan warisan antar generasi atau turun temurun sedangkan setiap karya intelektual merupakan hasil kreasi individu atau badan hukum;

2) Pencipta karya pengetahuan tradisional atau ekspresi budaya tradisional umumnya tidak dikenal lagi sedangkan pada hak intelektual masih diketahui;

3) Pemanfaatan hasil pengetahuan tradisional atau ekspresi budaya tradisional, utamanya ditujukan untuk prosesi, upacara adat atau keyakinan sedangkan pada kekayaan intelektual terkait dengan kepentingan komersial;

4) Kepemilikan pada pengetahuan tradisional maupun ekspresi budaya tradisional bersifat komunal sedangkan kepemilikan kekayaan intelektual adalah individual dan eksklusif; 
5) Waktu proteksi atau jangka waktu perlindungan untuk karya pengetahuan tradisional dan ekspresi budaya tradisional, tanpa batas waktu sedangkan pada kekayaan intelektual bervariasi tergantung jenis obyek perlindungannya.

Mengingat bahwa karya Ekspresi Budaya Tradisional merupakan warisan antar generasi atau secara turun temurun, maka pasal 38 ayat (1) Undang Undang Nomor 28 Tahun 2014 tentang Hak Cipta mengatur bahwa hak cipta atas ekspresi budaya tradisisional tersebut dipegang oleh negara dan pasal 38 ayat (2) menyatakan bahwa negara wajib menginventarisasi, menjaga dan memeliharanya.

Apakah rezim Hak Kekayaan Intelektual tetap efektif melindungi Ekspresi Budaya Tradisional? Penerapan perlindungan Ekspresi Budaya Tradisional tentu berangkat dari pikiran bahwa hal itu bertujuan melindung bukan saja aset masyarakat pengembannya, tetapi sebagai aset warisan budaya suatu bangsa. Oleh karenanya untuk melindungi, melestarikan dan memanfaatkannya dapat dilakukan dengan berbagai metode, diantaranya adalah pendekatan hukum hak kekayaan intelektual yang telah disepakati secara internasional. Perlu kembali diingat bahwa rezim Hak Kekayaan Intelektual adalah rezim yang sama sekali berbeda dengan karakteristik Ekspresi Budaya Tradisional. Hak Kekayaan Intelektual adalah rezim individualistik untuk memonopoli terutama invensi teknologi yang melindungi kepentingan pemilik industri.

Konsekuensi penerapan konsep barat melalui perlindungan Hak Kekayaan Intelektual pada Ekspresi Budaya Tradisional akan membawa dampak sebagai berikut:

a) Ekspresi BudayaTradisional dianggap hanya sebagai benda;

b) Ekspresi Budaya Tradisional diturunkan derajatnya hanya sebuah obyek hak milik individu; c) Untuk memperoleh hak milik Ekspresi Budaya Tradisional perlu langkah invensi tertentu;

d) Ekspresi Budaya Tradisional dijadikan obyek komersialisasi;

e) Nilai moral yang luhur yang seharusnya dijunjung tinggi menjadi nilai pasar.

Banyak faktor yang memperlihatkan bahwa penerapan konsep barat melalui perlindungan hak kekayaan intelektual terhadap Ekspresi Budaya Tradisional di dalam Undang Undang Hak Cipta, tidak selalu sejalan dengan konsepsi kepemilikan hak komunal yang berlaku pada masyarakat adat (pengemban) Ekspresi Budaya Ttradisional.

\section{Tidak ada peraturan pelaksanaan}

Sebelum diberlakukannya Undang Undang Nomor 28 Tahun 2014 tentang Hak Cipta, melalui Undang Undang Nomor 19 Tahun 2002 tentang Hak Cipta, selama ini pemerintah telah mengarahkan kebijakan perlindungan atas karya intelektual sesuai rezim Hak Kekayaan Intelektual terhadap karya kreasi seni Ekspresi Budaya Tradisional. Pemerintah mengakomodasi keduanya, walaupun titel perundangan yang mengaturnya berpegang pada konsepsi Hak Kekayaan IntelektuaI, tetapi substansi norma perlindungan hukumnya melindungi Ekspresi Budaya Tradisional.

Undang Undang Nomor 19 Tahun 2002 tentang Hak Cipta, pada rumusan pasal 10 ayat (1) disebutkan bahwa suatu ciptaan tidak saja terdiri dari karya orisinal di bidang ilmu pengetahuan, seni dan sastra tetapi juga karya peninggalan prasejarah, sejarah dan budaya nasional; serta folklore dan hasil kebudayaan rakyat menjadi milik bersama seperti, cerita rakyat, dongeng, legenda, babat, lagu, kerajinan tangan, koreografi, tarian, kaligrafi dan karya seni lainnya (pasal 10 ayat 2). Terhadap berbagai karya Ekspresi Budaya Tradisional itu, pemerintah bertindak sebagai pemegang hak ciptanya, termasuk di sini memberikan izin 
ketika orang yang bukan warga negara Indonesia bermaksud mengumumkan atau memperbanyak (pasal 10 ayat 3 ).

Tetapi dalam pelaksanaannya, tidak diatur lebih lanjut misalnya tentang mekanisme royalty pemanfaatan ekonomi karya Ekspresi Budaya Tradisional yang diijinkan oleh pemerintah untuk dimanfaatkan oleh pihak lain (asing), kepada siapakah akan diberikan royalty tersebut selaku kuasa wakil masyarakat adat (pengemban) Ekspresi Budaya Tradisional serta berapa prosentase besarnya royalty tersebut belum diatur melalui peraturan pemerintah. Sampai Undang Undang Hak Cipta tersebut dicabut, peraturan pemerintah yang diharapkan tidak pernah dikeluarkan.

\section{Sikap Apatis Masyarakat}

Undang Undang Nomor 19 Tahun 2002 tentang Hak Cipta tidak secara eksplisit disebutkan siapa yang dimaksud "masyarakat" pemilik kesenian atau folklore sebagai aset warisan budaya nasional. Sedangkan Berdasar ketentuan pasal 38 ayat (3) Undang Undang Nonor 28 Tahun 2014 tentang Hak Cipta, masyarakat pengemban Ekspresi Budaya Tradisional adalah masyarakat asal tempat Ekspresi Budaya Tradisional yang memelihara, mengembangkan serta melestarikannya. Setiap pemanfaatan Ekspresi Budaya Tradisional wajib memperhatikan adat istiadat, norma hukum adat maupun norma sosial yang ada pada masyarakat pemilik (kustodian) Ekspresi Budaya Tradisional.

Ada dugaan bahwa selama ini, sikap masyarakat pengemban Ekspresi Budaya Tradisional tidak peduli atau acuh tak acuh terhadap terjadinya penyalahgunaan Ekspresi Budaya Ttradisional leluhurnya. Sikap acuh tak acuh demiian ini bisa disebabkan oleh beberapa hal, misalnya:

(1) Disebabkan kurangnya pengetahuan atau informasi atas status hukum Ekspresi Budaya Tradisional atau,
(2) Mereka sama sekali tidak memahami konsep Hak Kekayaan Intelektual, apalagi memanfaatkannya untuk kepentingan pribadi.

Sikap tersebut mencerminkan tentang ketidakpedulian melindungi Ekspesi Budaya Tradisional dari tindakan kalim sepihak pihak asing. Akibatnya tidak ada kecurigaan atau keberatan sedikitpun bahwa klaim sepihak tersebut sebagai pelanggaran atas hak eksklusif warisan budaya leluhurnya.

Jika pandangan sebagian masyarakat tidak memerlukan perlindungan secara eksklusif untuk memperoleh keuntungan ekonomi, lalu apa sesungguhnya yang diperlukannya untuk melindungi Ekspresi Budaya Tradisional tersebut?

Hal ini bisa jadi manyarakat pengemban menganggap Ekspresi Budaya Tradisional sebagai sesuatu yang lebih bersifat spititual atau sakral. Jadi sudut pandang tersebut bertolak belakang dengan konsep perlindungan dalam rezim Hak Kekayaan Intelektual berasal dari masyarakat barat yang bersifat individualistik, sehingga obyek Ekspresi Budaya Tradisional, dapat dikomersialkan sebagai hak kebendaan atas benda tidak berwujud.

\section{Sistem Teknologi informasi Ekspresi Budaya Tradisional}

Berdasarkan pasal 64 ayat (1) Undang Undang Nomor 28 Tahun 2014, Pemerintah sebagai pemegang hak cipta Ekspresi Budaya Tradisional berkewajban untuk melaksanakan administrasi "pencatatan" dan "penghapusan" obyek hak cipta antara lain melalui sistem teknologi infomasi. Pencatatan ini bukan merupakan kewajiban bagi pencipta, pemegang hak cipta atau pemilik hak terkait karena Undang Uindang Nomor 28 tentang Hak Cipta menganut sistem perlindungan negatif (negative system) yang berarti perlindungan suatu ciptaan dimulai sejak ciptaan itu ada atau 
terwujud dan bukan karena pencatatan atau pendaftaran.

Dengan demikian tujuan pencatatan Ekspresi Budaya Tradional tersebut mepunyai tujuan antara lain:

1) Sebagai pangkalan data (database system) atau dokumentasi "akurat" bagian dari inventarisasi Ekspresi Budaya Tradisional oleh pemerintah sesuai ketentuan pasal 6 Undang Undang Nomor 28 Tahun 2014 tentang Hak Cipta, yang dapat dijadikan sebagai pendukung klaim oleh pemerintah kepada pihak asing, bahwa warisan budaya tersebut secara turun temurun berasal dari Indonesia;

2) Melindungi hak moral Ekspresi Budaya Tradisional yang melekat secara abadi;

3) Sarana publikasi Ekspresi Budaya Tradisional.

Permohonan pencatatan tersebut diajukan oleh pencipta atau pemegang hak cipta atau kuasanya kepada pemerintah, dalam hal ini Direktorat jenderal Hak Kekayaan Intelektual dengan:

a. Menyertakan contoh ciptaan dan kompilasi ciptaan yang aseli (original);

b. Melampirkan surat pernyataan kepemilikan ciptaan;

c. Membayar biaya.

Selama ini pihak pemerintah melalui Dirjen Hak Kekayaan Intelektual, telah menciptakan sistem informasi elektronik dalam mencatat dan menginventarisir berbagai bentuk karya Ekspresi Budaya Tradisional yang ada di tanah air, walaupun harus diakui belum berjalan secara maksimal. Oleh karenanya Pemerintah Daerah selaku kustodian, lebih aktif melakukan inventarisasi karya Ekspresi Budaya Tradisional di daerahnya masing-masing dan melakukan pencatatan melalui sistem informasi elektronik yang tersedia.

Memang terdapat beberapa permasalahan teknis dalam mengajukan permohonan pendaf- taran tersebut, tetapi yang menjadi kendala utama biasanya ada kesulitan untuk membuktiklan bahwa karya Ekspresi Budaya Tradisional tersebut asli (original) berasal dari masyarakat pengembannya

Ditingkat pemerintah pusat, telah dilakukan upaya perlindungan defensif Ekspresi Budaya Tradisional secara melalui kerja sama dan komunikasi antara Kementerian Pendidikan dan Kebudayaan dengan Kementrian Hukum dan Hak Asasi Manusia yang bertujuan meningkatkan efektifitas untuk menginventarisasi, memelihara dan menjaga Pengetahuan Tradisional dan Ekspresi Budaya Tradisional, dengan ruang lingkup sebagai berikut:

a. Penyediaan data base pengetahuan tradisional dan ekspresi budaya tradisional;

b. Pengelolaan informasi data pengetahuan tradisional dan ekspresi budaya tradisional;

c. Penyediaan materi, fasilitator dan narasumber untuk advokasi, sosialisasi, komunikasi, informasi dan edukasi pengetahuan tradisional dan ekspresi budaya tradisional;

d. Pelaksanaan koordinasi dan konsolidasi dalam rangka pentingnya inventarisasi, memelihara dan menjaga pengetahuan tradisional dan ekspresi budaya tradisional dengan SKPD Propinsi, Kabupaten/Kota dan masyarakat pengemban pengetahuan tradisional dan ekspresi budaya tradisional;

e. Peningkatan kemampuan bagi pemangku kepentingan untuk melakukan inventarisasi, memeilihara dan menjaga pengetahuan tradisional dan ekspresi budaya tradisional (www.kebuidayaan. kemendikbud.go.id, 2015).

\section{Pengawasan Masyarakat}

Di samping pihak pemerintah selaku pemegang hak cipta atas Ekspresi udaya Tradisional maka peran masyarakat pengemban karya Ekspresi Budaya Tradisional tersebut juga sangat penting untuk memelihara, menjaga dan melestari- 
kannya. Pengawasan ini penting untuk mengawal segala aktivitas pemanfaatan kreasi Ekspresi Budaya Tradisional baik dalam kegiatan bersifat non komersial, terlebih lagi untuk kegiatan eksploitasi yang tujuannya komerial.

Hal ini menjadi penting jika dihubungkan dengan perlindungan hak terkait, misalnya pada acara siaran oleh lembaga penyiaran, produser fonogram maupun oleh pelaku pertunjukan. Pengawasan ini secara tidak langsung akan menguntungkan, misalnya dari aspek publikasi pariwisata dan untuk menjaga hak moral Ekspresi Budaya Tradisional.

Pengawasan terrsebut tentunya tidak dapat sepenuhnya diserahkan kepada pemegang hak ciptanya yakni pemerintah. Oleh karenanya diperlukan kepedulian yang tinggi dari seluruh lapisan masyarakat pengemban Ekkspresi Budaya Tradisional bersangkutan. Tujuan lain dari pengawasan oleh masyarakat pengemban adalah menjaga penyalahgunaan secara komersial Ekspresi Budaya Tradisional dan sekaligus menjaga eksistensi hak moralnya.

\section{RUU PTEBT}

Bersamaan dengan diundangkannya RUU UUHC menjadi undang undang, sebenarnya pada waktu yang sama pemerintah juga telah mengajukan RUU Perlindungan dan Pemanfaatan Hak Kekayaan Intelektual Pengetahuian Tradisional dan Ekspresi Budaya Tradisional (RUU PTEBT) dalam prolegnas 2014, sebagai bagian sistem perundangan sui generis dalam perlindungan Ekspresi Budaya Tradisional. Belum diundangkannya RUU PTEBT bisa jadi karena mempertimbangkan secara matang terkait dengan dua prinsip dasar yang harus diterapkan yaitu apakah mengacu pada "Pelestarian budaya" atau "Perlindungan hukumnya".

Dalam konteks pelestarian budaya, siapa saja boleh melestarikan produk budaya tradisional.
Baik penduduk asli atau asing yang tertarik dapat menggunakan atau mempelajari agar tetap lestari. Sedangkan dari konteks perlindungan hukum, maka hanya orang yang berhak atau yang memperoleh ijin yang berhak menggunakan dan memanfaatkannya. Hal ini ada pihak-pihak yang dilarang untuk memanfaatkannya khususnya orang asing terutama jika menggunakan Ekspresi Budaya Tradisional itu untuk tujuan komersil. (Febe Bachtiar, 2016).

Sehubungan dengan penggunaan Ekspresi Budaya Tradisional oleh pihak asing, pasal 2 huruf (c) Undang Undang Nomor 28 Tahun 2014 tentang Hak Cipta, telah mengatur bahwa semua ciptaan dan atau produk hak terkait dan pengguna ciptaan dan produk hak terkait bukan warga negara Indonesia, bukan penduduk Indonesia dan bukan badan hukum Indonesia dengan ketentuan:

a. Negaranya mempunyai perjanjian bilateral dengan Republik Indonesia mengenai perlindungan hak cipta dan hak terkait; atau

b. Negaranya dan negara Republik Indonesia merupakan pihak atau peserta dalam perjanjian multilateral yang sama mengenai perlindungan hak cipta dan hak terkait.

\section{Penutup}

1. Untuk menerapkan sistem sui generis dalam upaya meningkatkan perlindungan terhadap kreasi Ekspresi Buydaya Tradisional, sebaiknya segera mengundangkan RUU PTEBT menjadi undang undang, selain Undang Undang Nomor 28 Tahun 2014 tentang Hak Cipta.

2. Agar pelaksanaan penegakan hukum sebagaimana telah diatur dalam Undang Undang Nomor 28 Tahun 2014 berjalan dengan baik, Pemerintah segera mengeluarkan Peraturan Pemerintah sebagaimana ditentukan undang undang tersebut. 


\section{Perlindungan Hukum terhadap Ekspresi Budaya Tradisional dalam Perspektif Undang Undang Hak Cipta}

Hendra Djaja

\section{DAFTAR PUSTAKA}

\section{Buku}

Ismaniyati, Neni Sri, 2010. Perlindungan HKI Sebagai Upaya Pemenuhan Hak Atas IPTEK, Budaya dan Seni, Jurnal Media Hukum.

James, TC, 2011. An Overview of Intellesctual Property Rights, National Intellectual Property Organisation.

Rancangan Undang Undang tentang PT dan EBT.

UNESCO,The Convention for The Safeguarding of The Intangible Cultural Heritage.

WIPO-IGC, Draft Provisions for The Protection of Traditional Cultural Expressions of Folkore.

WIPO-IGC, Draft Provisions for The Protection of Traditional Knowledge.

UN, The Convention on Biological Diversity 1992.
Peraturan Perundang-Undangan

Undang Undang Malaysia Tahun 2005 AKTA 645 tentang Warisan Kebangsaan.

\section{Internet}

Nota Kesepahaman Kemdikbud dengan Kemenkumham Nomor 124/F.F1/HK/2014 dan Nomor:HKI. HM.05.02.03, www.kebudayaan.kemendikbud.go.id, diakses tanggal 10 Nopember 2016.

Adimihardja, Kusnaka, HKI Mengatasi BIO-Piracy Global dalam http://www.pikiran-rakyat.com. Diakses tanggal 12 Desember 2016.

Febe Bachtiar, Perlindungan Hukum Ekspresi Budaya Tradisional Dalam Rangka Pemanfaatan Potensi Ekonomi Masyarakat Adat Jepara, www.ui.ac.id. Diakses tanggal 7 Desember 2016.

Sukandar, Dadang, Melindungi Pengetahuan Tradisional Sistem HKI Vs Sistem Sui Generis dalam http:// www.sinarharapan.co.id. Diakses tanggal 12 Desember 2016. 